\title{
Does Center Volume Correlate with Survival from Breast Cancer?
}

\author{
Anton Scharl $^{\mathrm{a}} \quad$ Uwe-Jochen Göhring ${ }^{\mathrm{b}}$ \\ ${ }^{a}$ Brustzentrum, Klinikum St. Marien Amberg, \\ ${ }^{\mathrm{b}}$ Brustzentrum, Johanniterkrankenhaus Bonn, Germany
}

Key Words

Breast cancer · Caseload · Survival · Specialization

\section{Summary}

With its high incidence and long history of patient advocacy, breast cancer has generated the most concern about the quality of its care and the volume-outcome relationship. In breast cancer surgery, the risk of perioperative morbidity or mortality is low, but surgery is only one single piece in the mosaic of multidisciplinary care that eventually determines survival. Only a limited number of articles is available investigating the relationship between case volume of physicians and hospitals and specialization of surgeons and survival. In summary, there is evidence to support the hypothesis that specialization, research interest, and caseload of physicians and hospitals is positively correlated with providing state-of-the-art care and with survival. However, it is less clear what impact might be attributed to the surgical routine gained with increasing number of procedures compared to the deeper insight into the biology of breast cancer that comes with specialization in oncology and the weight of the multidisciplinary setting that is more easily established and maintained with a higher caseload.

\section{Introduction}

The relationship between hospital volume and patient outcome has come to the forefront of public debate in recent years. A correlation between high procedural volume of individual surgeons and hospitals and improved surgical outcome has been established in many studies for a broad range of surgical diseases. The majority of these studies have focused on techni-

\author{
Schlüsselwörter \\ Brustkrebs · Fallzahl · Überleben · Spezialisierung
}

\section{Zusammenfassung}

Aufgrund der hohen Inzidenz von Brustkrebs und des großen Stellenwerts in der öffentlichen Aufmerksamkeit erfährt die mögliche Beziehung zwischen Fallzahl und Behandlungsqualität großes Interesse. Mortalität und Morbidität der operativen Behandlung des Mammakarzinoms sind gering, aber die Chirurgie ist nur ein Steinchen im Mosaik der multimodalen Therapie, die schließlich die Überlebenschancen bestimmt. Nur eine begrenzte Anzahl von Arbeiten untersuchte die Beziehung zwischen der Fallzahl von Ärzten und Kliniken und der Spezialisierung der Operateure und dem Überleben. Zusammenfassend gibt es überzeugende Belege dafür, dass Spezialisierung, Interesse an Forschung und die Anzahl von Brustkrebspatienten von Ärzten und Krankenhäusern positiv mit State-of-the-Art-Behandlung und Heilungswahrscheinlichkeit korreliert. Aber es ist weniger klar, ob dies durch die operative Routine bewirkt wird, die mit zunehmender Eingriffszahl steigt, oder durch die durch Spezialisierung geförderte tiefere Einsicht in die Biologie des Brustkrebses und den Einfluss eines multidisziplinären Aufbaus, der bei höherer Fallzahl leichter einzurichten und zu erhalten ist.

cally challenging high-risk procedures which have the inherent risks of significant morbidity and mortality, such as transplantation, pancreaticoduodenectomy and coronary artery bypass graft [1-5]. Other research has demonstrated better patient outcomes in teaching versus non-teaching hospitals $[6,7]$.

Studies have found various non-treatment factors associated with better outcome. Patient factors are the most obvious. Patients with less education or lower income and/or co-

\section{KARGER}

Fax +497614520714

Information@Karger.de

www.karger.com (c) 2009 S. Karger GmbH, Freiburg

Accessible online at:

www.karger.com/brc
Prof. Dr. Anton Scharl

Brustzentrum Amberg

Klinikum St. Marien

Mariahilfbergweg 5, 92224 Amberg, Germany

Tel. +49 9621 3813-71, Fax -58

scharl.anton@klinikum-amberg.de 
morbidity commonly have poorer outcomes [8]. A patient's insurer may affect access to care and coordination of services by creating barriers to referral [9]. Geographic variation in care, especially surgery, is well known [10].

\section{European Society of Mastology Breast Cancer Center}

In breast cancer surgery, the risk of perioperative morbidity or mortality is low. With its high incidence and long history of patient advocacy, breast cancer has generated the most concern about the quality of its care and the volume-outcome relationship.
The European Society of Mastology (EUSOMA) established a working party to consider what a specialist service for breast care should comprise. In 2000, the 'Requirements of a Breast Unit' were published and represent the opinion of the EUSOMA on the standards required for creating high-quality breast cancer units across Europe. They call for a minimum volume of 150 and 50 primary cases for a unit and for a single breast surgeon, respectively [11].

For breast cancer, the literature provides a limited number of studies that tested for the correlation of case volume of surgeons and hospitals with survival. An overview is shown in tables 1-3. The specific processes that lead to or that are associated with superior outcomes have not been deciphered. Al-

Table 1. Studies that showed a statistically significant relation between provider caseload and survival in breast cancer patients

\begin{tabular}{|c|c|c|c|c|c|c|c|c|}
\hline Author & Patients, $\mathrm{n}$ & Stage & $\begin{array}{l}\text { Hospital, case } \\
\text { volume }\end{array}$ & $\begin{array}{l}\text { Surgeon, } \\
\text { case volume }\end{array}$ & $\begin{array}{l}\text { Odds ratio, } \\
\text { death }\end{array}$ & $95 \%$ CI & $\begin{array}{l}\text { Year(s) of } \\
\text { treatment }\end{array}$ & Country \\
\hline $\begin{array}{c}\text { Sainsbury et al., } \\
1995 \text { [12] }\end{array}$ & 12,861 & all & & $\begin{array}{l}<30 \\
\geq 30 \\
<10 \\
10-29 \\
30-49 \\
>50\end{array}$ & $\begin{array}{l}1 \\
0.85 \\
1.16 \\
1.14 \\
0.98 \\
1\end{array}$ & $\begin{array}{l}0.77-0.93 \\
1.06-1.27 \\
1.07-1.21 \\
0.90-1.05\end{array}$ & 1979-1988 & Yorkshire (UK) \\
\hline $\begin{array}{c}\text { Roohan et al., } \\
1995 \text { [20] }\end{array}$ & 47,890 & all & $\begin{array}{l}\leq 10 \\
11-50 \\
51-150 \\
>150\end{array}$ & & $\begin{array}{l}1.60 \\
1.30 \\
1.19 \\
1\end{array}$ & $\begin{array}{l}1.42-1.81 \\
1.22-1.37 \\
1.12-1.25 \\
1\end{array}$ & & $\begin{array}{l}\text { New York State } \\
\text { (USA) }\end{array}$ \\
\hline $\begin{array}{l}\text { Mikeljevic et al., } \\
\quad 2003 \text { [13] }\end{array}$ & 11,329 & all & & $\begin{array}{l}<10 \\
10-29 \\
30-49 \\
>50\end{array}$ & $\begin{array}{l}1.15 \\
1.10 \\
1.01 \\
1\end{array}$ & $\begin{array}{l}1.03-1.28 \\
1.02-1.18 \\
0.93-1.08\end{array}$ & 1989-1994 & Yorkshire, UK \\
\hline $\begin{array}{l}\text { Skinner et al., } \\
\quad 2003 \text { [17] }\end{array}$ & 29,666 & all & $\begin{array}{l}1-35 \\
36-70 \\
71-125 \\
>125\end{array}$ & $\begin{array}{l}1-5 \\
6-10 \\
11-15 \\
>15\end{array}$ & $\begin{array}{l}1 \\
0.95 \\
0.90 \\
0.84 \\
1 \\
0.92 \\
0.78 \\
0.77\end{array}$ & $\begin{array}{l}0.88-1.02 \\
0.83-0.98 \\
0.77-0.92 \\
\\
0.85-0.99 \\
0.72-0.85 \\
0.70-0.84\end{array}$ & 1990-1998 & $\begin{array}{l}\text { Los Angeles } \\
\text { County, CA }\end{array}$ \\
\hline $\begin{array}{r}\text { Guller et al., } \\
2005 \text { [23] }\end{array}$ & 233,247 & localized & $\begin{array}{l}<30 \\
\geq 30 \text { to }<70 \\
\geq 70 \\
<30 \\
\geq 30 \text { to }<70 \\
\geq 70\end{array}$ & & $\begin{array}{l}\text { BCT } \\
3.04 \\
1.60 \\
1 \\
\mathrm{Mx} \\
1.90 \\
1.78 \\
1\end{array}$ & $\begin{array}{l}0.97-3.70 \\
0.95-3.30\end{array}$ & 1988-2000 & USA \\
\hline $\begin{array}{l}\text { Hèbert-Croteau } \\
\text { et al., } 2005 \text { [25] }\end{array}$ & 1,727 & $\mathrm{~N}-$ & $\begin{array}{l}<25 \\
25-49 \\
50-99 \\
\geq 100\end{array}$ & & $\begin{array}{l}1.80 \\
1.44 \\
1.30 \\
1\end{array}$ & $\begin{array}{l}1.23-2.63 \\
1.03-2.03 \\
0.96-1.76\end{array}$ & 1988-1994 & Quebec (Canada) \\
\hline
\end{tabular}


Table 1. Continued

\begin{tabular}{|c|c|c|c|c|c|c|c|c|}
\hline Author & Patients, $\mathrm{n}$ & Stage & $\begin{array}{l}\text { Hospital, case } \\
\text { volume }\end{array}$ & $\begin{array}{l}\text { Surgeon, } \\
\text { case volume }\end{array}$ & $\begin{array}{l}\text { Odds ratio, } \\
\text { death }\end{array}$ & $95 \%$ CI & $\begin{array}{l}\text { Year(s) of } \\
\text { treatment }\end{array}$ & Country \\
\hline $\begin{array}{c}\text { Simunovic et al., } \\
2006 \text { [26] }\end{array}$ & 14,346 & all & $\begin{array}{l}<102 \\
103-158 \\
159-264 \\
\geq 265\end{array}$ & & $\begin{array}{l}1.2 \\
1.1 \\
1.1 \\
1\end{array}$ & $\begin{array}{l}1.0-1.4 \\
0.9-1.2 \\
0.9-1.2\end{array}$ & 1990-1995 & Ontario \\
\hline $\begin{array}{c}\text { Nomura et al., } \\
2006 \text { [19] }\end{array}$ & 4,333 & $\begin{array}{l}\text { all stages, } \\
30-65 \text { years }\end{array}$ & $\begin{array}{l}\leq 15 \\
16-36 \\
47-79 \\
94-123\end{array}$ & & $\begin{array}{l}1.65 \\
1.10 \\
0.98 \\
1\end{array}$ & $\begin{array}{l}1.38-1.98 \\
0.92-1.33 \\
0.82-1.18\end{array}$ & 1985-1991 & Osaka (Japan) \\
\hline $\begin{array}{l}\text { Bailie et al., } \\
2007 \text { [16] }\end{array}$ & 809 & all & & $\begin{array}{l}\leq 30 \\
>30 \\
<10 \\
10-50 \\
50-100 \\
>100\end{array}$ & $\begin{array}{l}1.47 \\
1 \\
1.63 \\
1.57 \\
1.02 \\
1\end{array}$ & $\begin{array}{l}1.09-1.96 \\
1.04-2.56 \\
1.14-2.18 \\
0.71-1.47\end{array}$ & 1996 & Northern Ireland \\
\hline $\begin{array}{l}\text { Chen et al., } \\
2008 \text { [18] }\end{array}$ & 13,360 & all & $\begin{array}{l}\leq 258 \\
259-585 \\
>585\end{array}$ & $\begin{array}{l}\leq 44 \\
45-200 \\
>201\end{array}$ & $\begin{array}{l}1 \\
0.768 \\
0.766 \\
1.00 \\
0.696 \\
0.674\end{array}$ & $\begin{array}{l}0.699-0.839 \\
0.695-0.850 \\
0.585-0.827 \\
0.572-0.795\end{array}$ & 1997-1999 & Taiwan \\
\hline
\end{tabular}

BCT, Breast-conserving therapy; Mx, mastectomy.

Table 2. Studies that showed no statistically significant relation between provider caseload and survival in breast cancer patients

\begin{tabular}{|c|c|c|c|c|c|c|c|c|}
\hline Author & Patients, $\mathrm{n}$ & Stage & $\begin{array}{l}\text { Hospital, } \\
\text { case volume }\end{array}$ & $\begin{array}{l}\text { Surgeon, } \\
\text { case volume }\end{array}$ & $\begin{array}{l}\text { Odds ratio, } \\
\text { death }\end{array}$ & $95 \%$ CI & $\begin{array}{l}\text { Year(s) of } \\
\text { treatment }\end{array}$ & Country \\
\hline $\begin{array}{c}\text { Twelves et al., } \\
2001 \text { [31] }\end{array}$ & 1,617 & M0 & $\begin{array}{l}1-9 \\
10-29 \\
\geq 30\end{array}$ & & $\begin{array}{l}1.07 \\
1.11 \\
1.0\end{array}$ & $\begin{array}{l}0.83-1.37 \\
0.91-1.35\end{array}$ & 1987 & Scottland \\
\hline $\begin{array}{c}\text { Nattinger et al., } \\
2007 \text { [22] }\end{array}$ & 12,216 & $\begin{array}{l}\text { I, II } \\
>66 \text { years }\end{array}$ & & $\begin{array}{l}<5 \\
5-9 \\
>10\end{array}$ & $\begin{array}{l}1 \\
1.0 \\
0.94\end{array}$ & $\begin{array}{l}0.84-1.20 \\
0.76-1.16\end{array}$ & 1994-1996 & USA \\
\hline
\end{tabular}

though there was considerable difference in what was referred to as high volume or low volume, most of the studies demonstrated significant survival benefit for patients treated in highvolume hospitals or by high-volume or specialized surgeons.

\section{Influence of Surgeon and Hospital Caseload on Outcome}

British groups paid special attention to the relevance of the individual physician's specialization and caseload rather than the volume of hospitals and suggested a beneficial effect of treatment by dedicated or high-volume surgeons. In 1995, Sainsbury and colleagues [12] reported an evaluation of 12,861 women by geographic district and individual surgeon between 1979 and 1988 in Yorkshire. Examination of differences in survival as a function of consultant caseload demonstrated a significant benefit in cases in which a surgeon's volume averaged more than 30 cases per year. In addition, patients of surgeons with higher rates of usage of chemotherapy and hormone therapy (regional mean usage $9.3 \%$, range $0-46 \%$ ) had prolonged survival. These results suggest that at least in part improved outcome is due to extended usage of a multidisciplinary approach. In a follow-up period [13] covering 11,329 
Table 3. Studies that tested for hospital/surgeon variables other than caseload (teaching status, community hospital, rural hospital, private hospital, etc.)

\begin{tabular}{|c|c|c|c|c|c|c|c|c|}
\hline Author & $\begin{array}{l}\text { Patients, } \\
\mathrm{n}\end{array}$ & $\begin{array}{l}\text { Tumor } \\
\text { stage }\end{array}$ & $\begin{array}{l}\text { Hospital, } \\
\text { variables }\end{array}$ & $\begin{array}{l}\text { Surgeon, } \\
\text { variables }\end{array}$ & $\begin{array}{l}\text { Odds ratio, } \\
\text { death }\end{array}$ & $95 \%$ CI & $\begin{array}{l}\text { Year(s) of } \\
\text { treatment }\end{array}$ & Country \\
\hline $\begin{array}{c}\text { Bonett et al., } \\
1991 \text { [28] }\end{array}$ & 2,589 & all & $\begin{array}{l}\text { large public }{ }^{\text {n.s. }} \\
\text { large private } \\
\text { small }^{\text {n.s. }}\end{array}$ & & no difference & & 1980-1986 & South Australia \\
\hline $\begin{array}{l}\text { Gillis et al., } \\
1996 \text { [14] }\end{array}$ & 3,786 & $\begin{array}{l}\text { all } \\
<75 \text { years }\end{array}$ & & $\begin{array}{l}\text { SI } \\
\text { no SI }\end{array}$ & $\begin{array}{l}0.84 \\
1\end{array}$ & $0.75-0.94$ & 1980-1988 & Scotland \\
\hline $\begin{array}{l}\text { Kingsmore et al., } \\
\quad 2003 \text { [15] }\end{array}$ & 7,197 & all & & $\begin{array}{l}\text { non-specialist } \\
\text { specialist }\end{array}$ & $\begin{array}{l}1 \\
0.83\end{array}$ & $0.75-0.92$ & 1980-1994 & Scotland \\
\hline $\begin{array}{c}\text { Skinner et al., } \\
2003 \text { [17] }\end{array}$ & 29,666 & all & $\begin{array}{l}\mathrm{CC}^{\text {n.s. }} \\
\text { non-CC } \\
\text { n.s. }\end{array}$ & $\begin{array}{l}\text { SO } \\
\text { non-SO }\end{array}$ & $\begin{array}{l}0.77 \\
1 \\
1.12 \\
1\end{array}$ & $0.97-1.29$ & 1990-1998 & $\begin{array}{l}\text { Los Angeles } \\
\text { County, CA }\end{array}$ \\
\hline $\begin{array}{c}\text { Simunovic et al., } \\
2006[26]\end{array}$ & 14,346 & all & $\begin{array}{l}\text { teaching }{ }^{\text {n.s. }} \\
\text { non-teaching }{ }^{\text {n.s. }}\end{array}$ & & $\begin{array}{l}1 \\
1.0\end{array}$ & $0.9-1.1$ & 1990-1995 & Ontario \\
\hline $\begin{array}{c}\text { Gutierrez et al., } \\
2008 \text { [24] }\end{array}$ & 24,834 & ductal & $\begin{array}{l}\text { teaching } \\
\text { community } \\
\text { comm high vol } \\
\text { comm low vol }\end{array}$ & & $\begin{array}{l}0.763 \\
1 \\
0.903 \\
1\end{array}$ & $0.828-0.984$ & 1994-2000 & Florida, USA \\
\hline $\begin{array}{l}\text { Hall et al., } \\
2004 \text { [29] }\end{array}$ & 7,117 & all & $\begin{array}{l}\text { rural }^{\text {n.s. }} \\
\text { non-rural } \\
\text { privs. } \\
\text { public }\end{array}$ & & $\begin{array}{l}1.19 \\
1 \\
0.92 \\
1\end{array}$ & $\begin{array}{l}1.06-1.33 \\
0.85-0.99\end{array}$ & 1982-1996 & $\begin{array}{l}\text { Western } \\
\text { Australia }\end{array}$ \\
\hline $\begin{array}{c}\text { Chaudhry et al., } \\
2001 \text { [27] }\end{array}$ & 938 & $\begin{array}{l}\mathrm{N}_{-} \\
>2 \mathrm{~cm} \\
\mathrm{~N}_{-} \\
<2 \mathrm{~cm}\end{array}$ & $\begin{array}{l}\text { teaching } \\
\text { community } \\
\text { teaching }^{\text {n.s. }} \\
\text { community }^{\text {n.s. }}\end{array}$ & & $\begin{array}{l}0.47 \\
1 \\
1.32 \\
1\end{array}$ & $\begin{array}{l}0.23-0.96 \\
0.73-2.32\end{array}$ & 1991 & $\begin{array}{l}\text { Ontario } \\
\text { (Canada) }\end{array}$ \\
\hline $\begin{array}{l}\text { Spilsbury et al., } \\
2005[30]\end{array}$ & 11,445 & all & $\begin{array}{l}\text { metro public } \\
\text { metro private } \\
\text { regional public } \\
\text { regional private }\end{array}$ & & $\begin{array}{l}1.0 \\
1.1 \\
1.5 \\
1.1\end{array}$ & $\begin{array}{l}1.0-1.2 \\
1.2-1.8 \\
0.8-1.5\end{array}$ & $1982-2000$ & $\begin{array}{l}\text { Western } \\
\text { Australia }\end{array}$ \\
\hline $\begin{array}{l}\text { Hèbert-Croteau } \\
\text { et al., } 2005 \text { [25] }\end{array}$ & 1,727 & $\mathrm{~N}-$ & $\begin{array}{l}\text { TRR } \\
\text { no TRR }\end{array}$ & & $\begin{array}{l}0.71 \\
1\end{array}$ & $0.49-0.80$ & 1988-1994 & $\begin{array}{l}\text { Quebec } \\
\text { (Canada) }\end{array}$ \\
\hline
\end{tabular}

$\mathrm{N}$-, node negative; CC, National Cancer Institute-designated cancer centers; metro, hospital in metropolitan area; TRR, hospital with either teaching/ on-site radiotherapy/research; SI, specialist interest; SO, members of the Society for Surgical Oncology; teaching, teaching hospital; comm high/low vol, high/low-volume community hospital.,

n.s. no statistically significant relation.

patients who were initially treated between 1989-1994, the chances of survival were still significantly lower in patients of low-volume physicians.

Gillis and Hole in 1996 [14] reported a similar assessment between 1980 and 1988, using the West of Scotland Cancer Registry with 3786 cases. Survival after 5 and 10 years was significantly superior when patients were treated by specialists compared with non-specialist surgeons. Specialists were defined as those who were involved in a dedicated breast clinic or clinical trials and who kept separate records of patients with breast cancer. A follow-up study covering an additional period until 1994 for a total of 7197 women demonstrated that this survival difference remained in the era of breast cancer screening [15]. 
Bailie and collaborators [16] from Northern Ireland adjusted for case-mix variables, but still found lower survival for patients treated in low-volume settings, using a surgeon caseload cut-off point of 30 cases per annum.

The importance of surgeon specialization is underscored by a study from the USA. Skinner et al. [17] studied the effect of surgeon and hospital dedication on survival after breast cancer treatment in Los Angeles County using 29,666 patients from the Cancer Surveillance Program database. Multivariate analysis indicated that the case volume of the hospitals was an independent predictor of 5-year survival, whereas formal designation as a National Cancer Institute-designated cancer center was not. Treatment by surgical oncologists (defined as membership in the Society for Surgical Oncology) significantly foretold improved survival and resulted in a $33 \%$ reduction in the risk of death at 5 years. Surgery by a specialist offered a survival advantage similar to treatment in a highest-volume hospital. The caseload of surgeons was also predictive, although thresholds were set comparably low. The effect of surgical specialization could not be entirely attributed to volume effects.

Two studies from Asian countries also suggested dependency of long-term survival on hospital case volume. Chen et al. [18] examined 5-year survival rates for breast cancer patients using the Taiwan National Health Insurance Research Database. Of the 13,360 breast cancer resection patients, the survival rates were $77.3 \%$ in the high-volume group (> 201 cases), $76.9 \%$ in the medium-volume group (45-200), and $69.5 \%$ in the low-volume group $(\leq 44)$. Survival rates, by hospital volume, were $77.3 \%$ for high-volume (> 585 cases), $74.5 \%$ for medium-volume (259-585) and $72.1 \%$ for low-volume hospitals $(\leq 258)$. The risk of death for patients treated by low-volume surgeons and in low-volume hospitals was up to 1.305 times $(\mathrm{p}<0.001)$ and 1.484 times $(\mathrm{p}<0.001)$ as high as the risk for those treated by high-volume surgeons and highvolume hospitals, respectively. They used very high cut-offs. In comparison, the hospital volumes that were evaluated by Nomura and collaborators [19] were well within the low-volume group of Chen et al. [18]. In their setting, Nomura et al. [19] ascertained that long-term survival is lower only if surgery is performed in very-low-volume hospitals ( $\leq 15$ cases/year). They utilized data from the Osaka Cancer Registry. Their survival analysis was restricted to 4333 female patients who were 30-64 years old. The relative 10 -year survival was $79.7 \%$ in the high-volume, $80.3 \%$ in the medium-volume, $78.2 \%$ in the low-volume, and $68.2 \%$ in the very-low-volume hospitals.

Additional evidence is reported in studies from North America addressing hospital factors associated with breast cancer survival. Roohan et al. [20] used New York State hospital discharge summaries that were linked to the state cancer registry. A significant association of higher hospital volume with better 5-year survival was identified. The highest-volume hospitals were associated with a $19-60 \%$ improvement in survival.
An earlier study by Lee-Feldstein et al. [21] also had found a correlation between volume and survival, but was flawed because lymph node involvement was unknown in $15 \%$ of patients and comorbidity was not included in the multivariate survival analysis.

Nattinger et al. [22] studied potential bias in the surgeon volume-outcome relationship by comparing the relationship of surgeon volume to breast cancer mortality and to mortality from other causes of death. They conducted an observational cohort study from tumor registry and Medicare claims data on 12,216 women of 66 years or older with stage I or II breast cancer. Women treated by high-volume surgeons, compared with those treated by low-volume surgeons, were not less likely to die of breast cancer but were significantly less likely to die of other causes (relative risk, $0.86 ; 95 \%$ confidence interval (CI), 0.75-0.98). There are several severe shortcomings in this study. The definition used for a high-volume surgeon ( $>10$ Medicare cases/year) is based only on Medicare patients and may not necessarily account for the real load of breast cancer cases and is still low volume with respect to the definition used in other studies. Furthermore, the study population is comparatively old and of low risk. Therefore, the surgeon volume-outcome relationship for these patients is potentially biased by the high probability of other causes of death.

The largest database was used by Guller and colleagues [23] with a total of 233,247 patients extracted from the $\mathrm{Na}$ tionwide Inpatient Samples. They underwent breast-conserving therapy (BCT) or mastectomy $(\mathrm{Mx})$ for localized breast cancer from 1988 to 2000. Patients operated on at low-volume hospitals were significantly more likely to die and had a significantly higher likelihood of postoperative complications (odds ratio $(\mathrm{OR})=1.73, \mathrm{p}=0.01$ for $\mathrm{BCT} ; \mathrm{OR}=1.44, \mathrm{p}<0.001$ for $\mathrm{Mx})$ compared with high-volume hospitals. Patients were also significantly less likely to undergo BCT if operated on in a low- or intermediate-volume hospital compared with a highvolume provider $(\mathrm{p}<0.001)$.

\section{Influence of Hospital Setting on Outcome}

This association between hospital setting and state-of-the-art treatment and survival was also demonstrated by Gutierrez et al. [24]. They compared treatment patterns and long-term outcomes between teaching and community hospitals, utilizing 24,834 operative cases of infiltrating ductal carcinoma from the Florida Cancer Data System. Teaching hospitals treated $11.3 \%$ of patients with a larger proportion of stage III and IV disease (39.8\% vs. $33.0 \%$ ). BCT was more frequently performed at teaching hospitals $(41.5 \%$ vs. $38.9 \%$, p < 0.008$)$. On multivariate analysis, treatment at a teaching hospital was a significant independent predictor of improved 5- and 10-year overall survival even when compared to high-volume community hospitals. Since examination of practice patterns demonstrated that multimodality therapy was most frequently ad- 
ministered in teaching hospitals, poorer long-term outcomes at community hospitals seem to be, at least in part, caused by decreased use of proven life-extending adjuvant therapies.

Studies from Canada also suggest that hospital characteristics might be more important than pure caseload. HèbertCroteau et al. [25] from Quebec proposed that the relation between case volume and survival is mediated by factors related to the proficiency of care, which tends to cluster within institutions. The authors selected 1727 node-negative breast cancer patients from Quebec with a median follow-up of 6.8 years. Primary treatment of early-stage breast cancer in larger hospitals was associated with improved survival, but the significance of caseload disappeared after adjusting for the type of hospital. By contrast, women who were treated in centers with either on-site radiotherapy, research activity, or teaching status had significantly better outcomes, even after adjusting for caseload (hazard ratio (HR), 0.68; 95\% CI, 0.50-0.92).

Simunovic et al. [26] tested the role of hospital characteristics, such as procedure volume and teaching status, on the survival of 14,346 breast cancer patients in Ontario. The risk of long-term death was increased in low-volume versus highvolume hospitals. But there were no significant differences in the odds of operative (in-hospital) death or risk of long-term death among patients treated in teaching compared with nonteaching hospitals.

Chaudhry and colleagues [27] used a cohort consisting of a random sample of 938 node-negative breast cancer patients from Ontario to understand how treatment at teaching or community hospitals might affect survival. Multivariate proportional hazard regression modeling demonstrated a $53 \%$ relative reduction in risk of death among women with tumors less than or equal to $20 \mathrm{~mm}$ in diameter who were treated at a teaching hospital, whereas among those with larger tumors there was no demonstrated difference in survival. This might indicate that scrutiny in selecting patients for adjuvant therapy might be the key factor that differed between hospitals of different setting.

Bonett et al. [28] evaluated the 5-year survival by hospital type in South Australia of 2589 cases from 1980 to 1986 . No significant differences were found between large public, large private and smaller hospitals. However, other Australian studies support the notion that hospital setting is crucial for survival from breast cancer and more so than crude case volume. Hall et al. [29] used the Western Australian Record Linkage Project with 7117 breast cancer patients operated on between 1982 and 1996. After 5 years of follow-up, patients treated in rural hospitals had higher mortality rates than those treated in non-rural hospitals. Survival was higher in private hospitals compared to public hospitals. The survival disadvantage in rural hospitals was confirmed in another study based on the Western Australia Data Linkage System using 11,445 women treated between 1982 and 2000 [30]. A significantly increased mortality risk was observed for women who underwent initial surgical treatment in regional public hospitals outside of the state capital, Perth.
Twelves et al. [31] investigated breast cancer cases in Scotland initially treated in 1987 and suggested that the health board that is responsible for planning of multimodal treatment might be more important for survival than the caseload of surgeons. They investigated factors influencing the survival of women with early breast cancer in Scotland. Although they did not find a correlation between caseload of surgeons and survival probability in a multivariate analysis, there was a strong correlation between survival and health board. This was explained in part by the selection of patients for surgery, but there appeared to be a residual effect that may be related to differences in the use of adjuvant systemic treatment among the different health boards.

\section{Discussion}

Because of the significant impact of the operation on patient behavior, psychology, and appearance, evaluation of outcomes cannot be limited to operative mortality or morbidity. Choosing the appropriate type of surgery is as important as a sophisticated technical performance. For example, choosing sentinel node dissection where appropriate minimizes morbidity compared to an even most elaborate axillary dissection. Hospital and surgeon characteristics associated with the greater use of $\mathrm{BCT}$, such as teaching affiliation, larger caseload, on-site radiation therapy, and urban location, have been relatively consistent across studies [32]. However, over time, good practices of surgical care spread and get more widely adopted, as Fedeli et al. [33] demonstrated. For a region in Italy, they disclosed that the association of BCT with provider volume decreased as the growth over time in the recourse to BCT was steeper in low- and medium-volume hospitals.

Specialization is a successful approach to enhance the use of state-of-the-art techniques and improve short-term outcomes, as was demonstrated by Zork et al. [34]. For a single institution, they determined that, compared to general surgeons, dedicated breast cancer surgeons had higher percentages of BCT, sentinel node procedures and use of hormonal therapy, and lower percentages of positive or close margins, and re-excision. There were no differences in the use of adjuvant chemotherapy and radiation therapy.

In summary, there is evidence to support the hypothesis that case volume of surgeons and hospitals is somehow linked to survival from breast cancer, as is specialization of surgeons. However, it is less clear what impact might be attributed to the surgical routine gained with increasing number of procedures compared to the deeper insight into the biology of breast cancer that comes with specialization in oncology and the weight of the multidisciplinary setting. In the management of breast cancer, surgery is only one single piece in the mosaic of multidisciplinary care that eventually determines survival. In contrast to type of surgery, the use and type of adjuvant therapy does make a difference in survival. Most of the data 
presented in this article refer to times 10 and 20 years ago, when the benefit of adjuvant systemic therapy for almost all breast cancer patients was far from being generally accepted. Therefore, they might not be representative for today. The Surveillance Epidemiology and End Results (SEER) registry shows a steady increase in adjuvant therapies since the mid1980s [35].

To provide optimal patient care, extensive knowledge of other fields of medicine is required and the proper interaction of these different specialties is necessary. Most cancer centers have regular conferences with surgical or gynecologic oncologists, radiologists, pathologists, medical oncologists, and radiation oncologists to facilitate best care. Physician and hospital characteristics, such as specialty training focus, research interest, and case volume, should convey that the management is state-of-the-art. In high-volume units there might be a higher chance of providing superior coordination of care and multidisciplinary interaction, profound skills in different fields of breast oncology, maintenance of knowledge of the voluminous and quickly changing literature and expertise in patient education and assisting them through the decisionmaking process.

Since the perioperative risks associated with the primary therapy are low and given the high frequency of multimodal therapies, evidence leads to the assumption that superior longterm survival is rather the result of multidisciplinarity and superior coordination of care than of mere surgical skills.

What are the proper consequences? Should small hospitals and low-volume surgeons be barred from caring for breast cancer patients? There is no proof that big automatically means good. Twelves and colleagues [31] highlighted that the chances of survival might be more dependent on health boards that are considered expert than on a surgeon's experience. Furthermore there is a huge spread in the distribution of the cut-off levels used in the studies cited above for discriminating high and low volume. Where is the threshold to be set? On the other hand, do all patients want to go to high-volume hospitals? Bouche et al. [36] demonstrated, at least for France, that the answer is no.

It has been demonstrated that, with time, there is a diffusion of good practices of care [33]. Thus, it seems a wiser approach to facilitate this expansion by guidelines and continuous education and thereby boost widespread improvement of quality of care than to only establish high-volume centers. According to the evidence, a multidisciplinary setting with specialists and well-established interaction is most critical for offering best therapy. Therefore, breast care centers could serve as core institutions that offer specialist expertise to associate physicians and hospitals in a structured collaboration. These then could continue to serve their community and treat breast cancer patients but have the advantages of collegial discussion, and guidance.

\section{Conflict of Interest}

None of the authors received financial support for this article.

\section{References}

1 Reese PP, Yeh H, Thomasson AM, Shults J, Markmann JF: Transplant center volume and outcomes after liver retransplantation. Am J Transplant 2009;9: 309-317.

2 Ho V, Heslin MJ: Effect of hospital volume and experience on in-hospital mortality for pancreaticoduodenectomy. Ann Surg 2003;237:509-514.

-3 Rathore SS, Epstein AJ, Volpp KG, Krumholz HM: Hospital coronary artery bypass graft surgery volume and patient mortality, 1998-2000. Ann Surg 2004;239:110-117.

4 Billingsley KG, Morris AM, Green P, Dominitz JA, Matthews B, Dobie SA, Barlow W, Baldwin L-W: Does surgeon case volume influence nonfatal adverse outcomes after rectal cancer resection? J Am Coll Surg 2008;206:1167-1177.

5 Wilt TJ, Shamliyan TA, Taylor BC, MacDonald R, Kane RL: Association between hospital and surgeon radical prostatectomy volume and patient outcomes: a systematic review. J Urol 2008;180:820-829.

6 Holm T, Johansson H, Cedermark B, Ekelund G, Rutqvist LE: Influence of hospital- and surgeonrelated factors on outcome after treatment of rectal cancer with or without preoperative radiotherapy. Br J Surg 1997;84:657-663.

$\checkmark$ Taylor DH, Jr, Whellan DJ, Sloan FA: Effects of admission to a teaching hospital on the cost and quality of care for Medicare beneficiaries. N Engl J Med 1999;340:293-299.
8 Cella DF, Orav EJ, Kornblith AB, Holland JC, Silberfarb PM, Lee KW, Comis RL, Perry M, Cooper R, Maurer LH, Hoth DF, Perloff M, Bloomfield CD, McIntyre OR, Leone L, Lesnick G, Nissen N, Glicksman A, Henderson E, Barcoss M, Crichlow R, Faulkner III CS, Eaton W, North W, Schein PS, Chu F, King G, Chahinian A-P: Socioeconomic status and cancer survival. J Clin Oncol 1991;9:1500-1509.

$\checkmark 9$ Hadley J, Mitchell JM, Mandelblatt J: Medicare fees and small area variations in breast-conserving surgery among elderly women. Med Care Res Rev 2001:58;334-360.

10 Nattinger AB, Gottlieb MS, Veum J, Yahnke D, Goodwin JS: Geographic variation in the use of breast-conserving treatment for breast cancer. $\mathrm{N}$ Engl J Med 1992:326:1102-1107.

11 EUSOMA: The requirements of a specialist breast unit. Eur J Cancer 2000;36:2288-2293.

12 Sainsbury R, Haward B, Rider L, Johnston C, Round C: Influence of clinician workload and patterns of treatment on survival from breast cancer. Lancet 1995;345:1265-1270.

13 Mikeljevic JS, Haward RA, Johnston C, Sainsbury R, Forman D: Surgeon workload and survival from breast cancer. Br J Cancer 2003;89:487-491.

14 Gillis CR, Hole DJ: Survival outcome of care by specialist surgeons in breast cancer: A study of 3786 patients in the west of Scotland. BMJ 1996;312:145148.
15 Kingsmore D, Semwogerere A, Hole D, Gillis C: Specialisation and breast cancer survival in the screening era. Br J Cancer 2003;88:1708-1712.

16 Bailie K, Dobie I, Kirk S, Donnelly M: Survival after breast cancer treatment: the impact of provider volume. J Eval Clin Pract 2007:13:749-757.

17 Skinner KA, Helsper JT, Dennis Deapen D, Ye W, Sposto R: Breast cancer: Do specialists make a difference? Ann Surg Oncol 2003;10:606-615.

18 Chen C-S, Liu T-C, Lin H-C, Lien Y-C: Does high surgeon and hospital surgical volume raise the fiveyear survival rate for breast cancer? A populationbased study. Breast Cancer Res Treat 2008;110:349_ 356.

19 Nomura W, Tsukuma H, Ajiki W, Ishikawa O, Oshima A: Population-based study of the relationship between hospital surgical volume and 10-year survival of breast cancer patients in Osaka, Japan. Cancer Sci 2006;97:618-622.

20 Roohan PJ, Bickell NA, Baptiste MS, Therriault GD, Ferrara EP, Siu AL: Hospital volume differences and five-year survival from breast cancer. Am J Public Health 1998;88:454-457.

21 Lee-Feldstein A, Anton-Culver H, Feldstein PJ: Treatment differences and other prognostic factors related to breast cancer survival: Delivery systems and medical outcomes. JAMA 1994;271:1163-1168. 
22 Nattinger AB, Laud PW, Sparapani RA, Zhang X, Neuner JM, Gilligan MA: Exploring the surgeon volume-outcome relationship among women with breast cancer. Arch Intern Med 2007:167:1958-1963.

-23 Guller U, Safford S, Pietrobon R, Heberer R, Oertli D, Jain NB: High hospital volume is associated with better outcomes for breast cancer surgery: analysis of 233,247 patients. World J Surg 2005;29:994-1000.

24 Gutierrez JC, Hurley JD, Housri N, Perez EA, Byrne MM, Koniaris LG: Are many community hospitals undertreating breast cancer? Lessons from 24,834 patients. Ann Surg 2008;248:154-162.

25 Hèbert-Croteau N, Brisson J, Lemaire J, Latreille J, Pineault R: Investigating the correlation between hospital of primary treatment and the survival of women with breast cancer. Cancer 2005;104:13431348.

26 Simunovic M, Rempel E, Thériault M-E, Coates A, Whelan T, Holowaty E, Langer B, Levine M: Influence of hospital characteristics on operative death and survival of patients after major cancer surgery in Ontario. Can J Surg 2006;49:251-258.
27 Chaudhry R, Goel V, Sawka C: Breast cancer survival by teaching status of the initial treating hospital. CMAJ 2001;164:183-188.

28 Bonett A, Roder D, Esterman A: Case-survival rates for infiltrating ductal carcinomas by category of hospital at diagnosis in South Australia. Med J Aust 1991;154:695-697.

29 Hall S, Homan CD, Sheiner H, Hendrie D: The influence of socio-economic and locational disadvantage on survival after a diagnosis of lung or breast cancer in Western Australia. J Health Serv Res Policy 2004;9:10-16.

30 Spilsbury KS, Semmens JB, Saunders CM, Holman CDJ: Long-term survival outcomes following breast-cancer surgery in Western Australia. ANZ J Surg 2005; 75:625-630.

31 Twelves CJ, Thomson CS, Dewar JA, Brewster DH: Variation in survival of women with breast cancer: health board remains a factor at 10 years. Br J Cancer 2001;85:637-640.

32 Luther SL, Studnicki J: Physician practice volume and alternative surgical treatment for breast cancer in Florida. Health Serv Res 2001;36:166-179.
33 Fedeli U, Alba N, Schievano E, Visentin C, Rosato R, Zorzi M, Ruscitti G, Spolaore P: Diffusion of good practices of care and decline of the association with case volume: the example of breast conserving surgery. BMC Health Serv Res 2007;7:167-172.

34 Zork NM, Komenaka IK, Pennington RE, Bowling MW, Norton LE, Clare SE, Goulet RJ: The effect of dedicated breast surgeons on the short-term outcomes in breast cancer. Ann Surg 2008;248:280-285.

35 Mariotto AB, Feuer EJ, Harlan LC, Abrams J: Dissemination of adjuvant multiagent chemotherapy and tamoxifen for breast cancer in the United States using estrogen receptor information: 19571999. J Natl Cancer Inst Monogr 2006;36:7-15

36 Bouche G, Migeot V, Mathoulin-Pèlissier S, Salamon R, Ingrand P: Breast cancer surgery: Do all patients want to go to high-volume hospitals? Surgery 2008;143:699-705. 